\title{
24. GEOCHEMISTRY OF BASALTS ERUPTED AT THE GALAPAGOS SPREADING CENTER BETWEEN 85 AND $87^{\circ} \mathrm{W}^{1}$
}

\author{
R. Emmermann, Mineralogisch-Petrologisches Institut, Senckenbergstr. 3, 63 Giessen, Federal Republic of Germany \\ and \\ H-W. Hubberten and H. Puchelt, Institut für Petrographie und Geochemie, Kaiserstr. 12, 75 Karlsruhe, \\ Federal Republic of Germany
}

\begin{abstract}
New data relating to major and trace elements in basalts both drilled (DSDP Legs 70 and 54) and dredged (R/V Sonne cruise 12) in the Galapagos rift area are reported in this chapter. These results together with previously published analyses provide a rather complete picture of the composition of the uppermost part of Layer 2 in this region. The basalts recovered range from MORB-type tholeiites over $\mathrm{Fe}$ - and Ti-enriched tholeiites to FeTi-tholeiites and are connected by continuous chemical trends. These trends are explained as a result of intensive, shallow-depth fractional crystallization processes. Systematic variations in basalt composition exist along and across the rift axis. Zero-age basalts are most enriched in $\mathrm{FeO}^{\mathrm{T}}$ and $\mathrm{TiO}_{2}$, with both components increasing toward the east. Young crust basalts (mounds area) show only a limited variation and can be classified as $\mathrm{Fe}$ - and Ti-enriched tholeiites. Older crust basalts (up to 2.7 m.y.) have compositions of normal midocean-ridge tholeiites and are characterized by a strong depletion of light rareearth elements. There seems to be a systematic and cyclic compositional variation with age which might be explained by differentiation cycles.
\end{abstract}

\section{INTRODUCTION}

During the past few years the Galapagos Spreading Center (GSC) with its associated platform has become one of the best surveyed and most densely sampled areas of the ocean floor. Among the most striking features of this region are the unusually high amplitude magnetic anomalies which have been noted over the ridge crest from longitude $85^{\circ}$ to $95^{\circ} \mathrm{W}$ and which are largest over the ridge segment between $85^{\circ}$ to $87^{\circ} \mathrm{W}$ (Galapagos rift zone, i.e., the segment between the Galapagos and the Ecuador fracture zone). These large magnetic amplitudes have been attributed by Vogt and Johnson (1975) to an ocean crust rich in $\mathrm{Fe}$ and $\mathrm{Ti}$ (titanomagnetite), derived from a mantle plume upwelling beneath the Galapagos Archipelago. Anderson et al. (1975) also regarded $\mathrm{Fe}-$ and Ti-enrichment in basaltic rocks underlying this area as a source of the large amplitudes measured by both surface and deep-tow methods, but suggested that this enrichment was caused by intensive, shallow-depth fractional crystallization of "normal" (i.e., light) rareearth element depleted midocean-ridge tholeiitic melts generated within a melting anomaly centered about the Galapagos Islands.

Schilling et al. (1976) presented rare earth and major element data on basalts dredged along the GSC, which clearly show that there is no simple relationship between $\mathrm{Fe}$ and $\mathrm{Ti}$ contents of basalts and intensity of magnetic anomaly amplitudes and that the "telechemical idea" of correlating both remains an open question. On the one hand, very $\mathrm{Fe}$ - and Ti-rich basalts with up to $18 \% \mathrm{FeO}^{\mathrm{T}}$ (i.e., total) and up to $3.6 \% \mathrm{TiO}_{2}$ have been recovered

${ }^{1}$ Honnorez, J., Von Herzen, R. P., et al., Init. Repts. DSDP, 70: Washington (U.S. Govt. Printing Office). from the ridge segment where magnetic anomaly amplitudes are largest; on the other hand, basalts with relatively low $\mathrm{FeO}^{\mathrm{T}}$ and $\mathrm{TiO}_{2}$ also occur in this area, and outside the $85^{\circ}$ to $87^{\circ}$ region no such relationship with $\mathrm{Fe}$ and $\mathrm{Ti}$ could be established at all. Thus, only for the $85-87^{\circ}$ region a certain correlation between Fe enrichment and magnetic amplitude intensities seems to be valid. Schilling et al. also explain the unusually high $\mathrm{Fe}$ (and Ti) enrichment of the dredged basaltic material by extensive, shallow-depth crystal fractionation of normal midocean-ridge tholeiitic magmas, but in contrast to Anderson et al. (1975) emphasize that this mechanism is restricted to the $85-87^{\circ}$ region and cannot be applied to explain the chemical characteristics of basalt erupted outside this area, which according to their rare-earth element patterns have to be regarded as plume-derived. By modeling the rare-earth and major element variations of $85-87^{\circ}$ basalts, they conclude that the crystallization process is dominated by extraction of plagioclase, and to a lesser extent of olivine and clinopyroxene, and that there could be a connection between the intensive fractional crystallization and the hydrothermal activity, which is likewise very intensive in this area as compared with elsewhere on the GSC: "It is conceivable, that unusually intense hydrothermal circulation might have been removing heat more efficiently from a magma chamber generated by spreading, thus enhancing fractional crystallization before lava erupted on the sea floor. . . "' (Schilling et al., 1976).

We report here new geochemical data of basaltic material drilled and dredged within the crustal segment across the Galapagos rift zone between longitudes 85 and $87^{\circ} \mathrm{W}$. Together with results previously published by different authors these data will be used to answer some petrologically relevant questions. Among these are the following: What is the composition and variability 
of modern basalts erupted along the ridge axis of the GSC between $85^{\circ}$ and $87^{\circ} \mathrm{W}$ ? How do these rocks compare to older basalts erupted at the GSC, which have been recovered at different distances from the northern and southern flank of the rift zone? Is there any evidence for systematic variation of basalt composition across the ridge? What is the mode of formation of the $85-87^{\circ}$ region basalts?

\section{SAMPLE LOCATIONS}

All those localities from which basaltic material has been recovered are shown in Figure 1. Solid squares represent DSDP sites drilled by the Glomar Challenger and stars mark the stations of dredge hauls.

During Leg 54, the Glomar Challenger arilled Holes $424,424 \mathrm{~A}, 424 \mathrm{~B}$, and $424 \mathrm{C}$ about $22 \mathrm{~km}$ south of the rift axis of the GSC near $0^{\circ} 35^{\prime} \mathrm{N}$ and $86^{\circ} 07^{\prime} \mathrm{W}$ (see Table 1). These holes were cored at a distance of about 300 meters from each other along a N-S transect within

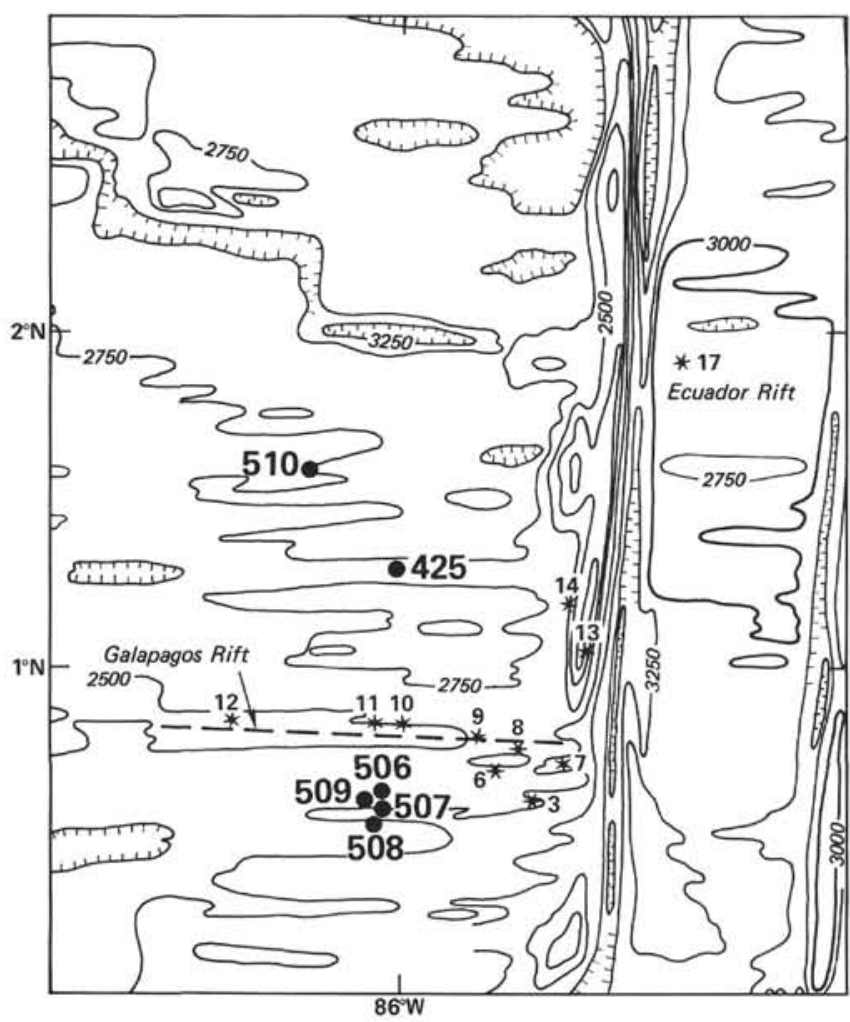

Figure 1. Location of DSDP sites (squares) and dredge stations (stars) around the Galapagos Rift.

Table 1. Location of DSDP sites.

\begin{tabular}{ccccccc}
\hline Leg & Site & $\begin{array}{c}\text { Authors' } \\
\text { No. }\end{array}$ & Latitude & Longitude & $\begin{array}{c}\text { Water } \\
\text { Depth } \\
(\mathrm{m})\end{array}$ & $\begin{array}{c}\text { Basement } \\
\text { Age } \\
(\mathrm{m} . \mathrm{y} .)\end{array}$ \\
\hline 70 & 508 & 1 & $0^{\circ} 32.0^{\prime} \mathrm{N}$ & $86^{\circ} 06.0^{\prime} \mathrm{W}$ & 2777 & 0.85 \\
70 & 507 & 2 & $0^{\circ} 34.0^{\prime} \mathrm{N}$ & $86^{\circ} 05.4^{\prime} \mathrm{W}$ & 2700 & 0.69 \\
54 & 424 & 4 & $0^{\circ} 35.7^{\prime} \mathrm{N}$ & $86^{\circ} 07.8^{\prime} \mathrm{W}$ & 2700 & 0.62 \\
70 & 506 & 5 & $0^{\circ} 36.5^{\prime} \mathrm{N}$ & $86^{\circ} 05.5^{\prime} \mathrm{W}$ & 2720 & 0.54 \\
54 & 425 & 15 & $1^{\circ} 23.7^{\prime} \mathrm{N}$ & $86^{\circ} 04.2^{\prime} \mathrm{W}$ & 2850 & 1.8 \\
70 & 510 & 16 & $1^{\circ} 36.8^{\prime} \mathrm{N}$ & $86^{\circ} 24.6^{\prime} \mathrm{W}$ & 2781 & 2.73 \\
\hline
\end{tabular}

the so-called geothermal field on crust 0.60 to $0.62 \mathrm{~m}$.y. old.

This mounds field occurs in an area between 18 and $32 \mathrm{~km}$ south of the rift axis at about $86^{\circ} \mathrm{W}$ longitude and extends approximately $27 \mathrm{~km}$ in an east-west direction. The Holes 424 and $424 \mathrm{~A}$ are on or very close to mounds and were both continuously cored through 31 to 29 meters of sediments and 45 to 5 meters of basaltic basement, respectively. Hole 424B drilled at about 300 meters north of Hole 424 in an area presumed to be off-mounds, encountered the basement at a sub-bottom depth of 32 meters and penetrated 14.5 meters into basaltic rock. Hole 424C, also an off-mound hole, reached a basement penetration of 3.0 meters.

Another hole, Hole 425, was drilled during Leg 54 at about $62 \mathrm{~km}$ north of the rift axis in a crust slightly older than $1.8 \mathrm{~m} . \mathrm{y}$. This hole, located in a sediment-filled topographic depression, is within or close to a zone of large amplitude magnetic anomalies. Basement penetration at this site was 28.5 meters with $19.6 \%$ recovery.

A total of 32 holes at five sites, one of them north (Hole 510) and four of them south (Holes 506, 507, 508, and 509) of the rift axis were drilled during the first part of DSDP Leg 70 (Table 1).

Site 510 is about $90 \mathrm{~km}$ north of the Galapagos Rift and $38 \mathrm{~km}$ west-northwest of Site 425 in an area of relatively high heat flow on crust estimated to be approximately $2.7 \mathrm{~m}$.y. old. Sediment thickness here was 115 meters; basement penetration reached 21 meters with $27 \%$ recovery. Sites 506, 507, and 508 are at a distance, respectively, of $19.5,23.5$, and $28 \mathrm{~km}$ south of the rift axis, also within the hydrothermal mounds area on crust between 0.54 and $0.85 \mathrm{~m} . \mathrm{y}$. old. Sediment thickness ranged from 30 to 52 meters. Site 509 is centered on a mounds field 21 to $22 \mathrm{~km}$ south of the Galapagos Rift and coincides with Site 424 of Leg 54.

The dredged material analyzed by us was obtained during the Geometep cruise of the German vessel R/V Sonne (1980) and was kindly placed at our disposal by the Preussag Meerestechnik. Locations of Sonne-12 dredge hauls are given in Table 2 along with sites of previous dredge hauls by $\mathrm{R} / \mathrm{V}$ Melville (cruise Cocotow 4), R/V T. Washington (cruise Southtow 7), and U.S.N.S. De Steiguer (cruise 41).

\section{PETROGRAPHIC SUMMARY}

Site 424 basalts. Basalts recovered from Holes 424, $424 \mathrm{~A}, 424 \mathrm{~B}$, and $424 \mathrm{C}$ are very similar and can be described as fine- to medium-grained aphyric tholeiites with occasional microphenocrysts of plagioclase. Their

Table 2. Location of dredge stations.

\begin{tabular}{|c|c|c|c|c|c|c|c|}
\hline Cruise & Dredge & $\begin{array}{c}\text { Authors' } \\
\text { No. }\end{array}$ & Latitude & Longitude & $\begin{array}{l}\text { Depth } \\
\text { (m) }\end{array}$ & $(\mathrm{La} / \mathrm{Sm})_{\mathrm{N}}$ & $\mathrm{Yb}_{\mathrm{N}}$ \\
\hline Sonne-12 & 138D & 3 & $0^{\circ} 35.0^{\prime} \mathrm{N}$ & $85^{\circ} 38.5^{\prime} \mathrm{W}$ & 2924 & 0.48 & 23.8 \\
\hline Sonne-12 & 108D & 6 & $0^{\circ} 42.1^{\prime} \mathrm{N}$ & $85^{\circ} 42.1^{\prime} \mathrm{W}$ & 2693 & 0.52 & 31.5 \\
\hline De Steiguer 41 & D-1 & 7 & $0^{\circ} 42.6^{\prime} \mathrm{N}$ & $85^{\circ} 30.0^{\prime} \mathrm{W}$ & 2377 & 0.68 & 44.8 \\
\hline Sonne-12 & 130D & 8 & $0^{\circ} 44.4^{\prime} \mathrm{N}$ & $85^{\circ} 34.6^{\prime} \mathrm{W}$ & 2728 & 0.63 & 39.0 \\
\hline Sonne-12 & $136 \mathrm{D}$ & 9 & $0^{\circ} 46.9^{\prime} \mathrm{N}$ & $85^{\circ} 46.4^{\prime} \mathrm{W}$ & 2703 & 0.53 & 23.8 \\
\hline Sonne-12 & 127D & 10 & $0^{\circ} 48.0^{\prime} \mathrm{N}$ & $85^{\circ} 59.2^{\prime} \mathrm{W}$ & 2564 & 0.58 & 23.2 \\
\hline Southtow 7 & 17D & 11 & $0^{\circ} 49.2^{\prime} \mathrm{N}$ & $86^{\circ} 07.8^{\prime} \mathrm{W}$ & 2500 & 0.68 & 26.7 \\
\hline Cocotow 4 & $6 \mathrm{D}$ & 12 & $0^{\circ} 51.1 \cdot \mathrm{N}$ & $86^{\circ} 32.8^{\prime} \mathrm{W}$ & 2380 & 0.60 & 25.1 \\
\hline De Steiguer 41 & D-3 & 13 & $1^{\circ} 02.3 \cdot \mathrm{N}$ & $85^{\circ} 25.4^{\prime} \mathrm{W}$ & 1554 & 0.40 & 14.9 \\
\hline De Steiguer 41 & D-4 & 14 & $1^{\circ} 08.6^{\prime} \mathrm{N}$ & $85^{\circ} 30.0^{\prime} \mathrm{W}$ & 2926 & 0.46 & 25.8 \\
\hline
\end{tabular}


textures range from glassy hyalopilitic or variolitic to intersertal and intergranular. Rock constituents are plagioclase, clinopyroxene, titanomagnetite, and variable amounts of glass. The content of titanomagnetite is approximately $10 \%$, and glass content varies from $10 \%$ to $25 \%$. Even relatively coarser-grained samples are not devoid of glassy patches, which contain needle-like opaques, dendritic clinopyroxene, and sometimes microphenocrysts of plagioclase. Different petrographic types have not been observed, neither intra- nor interhole.

Site 506 to 509 basalts. The basalts encountered at Sites 506 to 509 are petrographically akin to Site 424 basalts and are fine- to medium-grained aphyric to sparsely plagioclase phyric tholeiites. Microscopically, they display a series of textural varieties depending upon their cooling history: samples that are quenched exhibit variolitic, hyalopilitic, or intersertal textures, whereas relatively coarser-grained types show intergranular to subophitic textures. The crystalline phases present are plagioclase (An 55 to 65), commonly lath-shaped and composing up to $45 \%$ of rock, clinopyroxene, as subequant grains or needlelike crystals in fan-shaped arrangement, and opaques, mostly titanomagnetite, constituting 8 to $13 \%$ of rock and occurring as dissemination or skeletal crystals. Occasionally, primary sulfides in spherules can be observed. The glass content varies from less than $5 \%$ to more than $35 \%$; some basalt pieces were coated by fresh glassy rinds.

As with Site 424 basalts, alteration is slight and is mainly restricted to the occurrence of smectite in vesicles and voids. Sometimes, especially in variolitic and hyalopilitic varieties, alteration rims of up to $8 \mathrm{~mm}$ thick are developed. This alteration is caused by lowtemperature seawater interaction; alteration minerals of unequivocally hydrothermal origin do not occur.

Hole 425 basalts. Megascopically, these basalts show relatively large variations in color, vesiculation, grain size, and phenocryst assemblages. In general, they can be termed fine- to medium-grained, aphyric to phyric tholeiites without any significant alteration. From top to bottom three distinct petrographic types are recognizable: (I) Aphyric to sparsely phyric plagioclase-pyroxene basalts. They are fine-grained, vesicular rocks with intersertal to variolitic textures and are essentially made up of plagioclase, clinopyroxene, titanomagnetite, and glass; (II) Phyric to glomerophyric plagioclase-clinopyroxene \pm olivine basalts with glomerocrysts of plagioclase, pyroxene, and (more rarely) olivine, which are most likely of pre-eruption crystallization origin; and (III) Sparsely phyric plagioclase-pyroxene \pm olivine basalts. This type is found at the bottom of the hole. It contains grains of olivine as microphenocrysts as well as in the groundmass. The amount of iron oxide minerals is significantly lower than in Type I and II basalts.

Site 510 basalts. The basalts retrieved during the 21 meters of basement penetration at Site 510 differ significantly from young crust basalts recovered from the southern flank of the Galapagos rift. The main differences are: (1) their pronounced phyric appearance, which results from the presence of between 15 and $45 \%$ plagioclase phenocrysts; (2) the occurrence of olivine microphenocrysts, which may constitute up to $5 \%$ of the rock and are mainly replaced by different kinds of smectites; (3) their significantly lower content of $\mathrm{Fe}$ - Tioxides, which are only half as abundant (3-8\%) as in basalts from Sites 424 and 506 to 509 . In general these rocks can be classified as plagioclase-olivine phyric tholeiites. The plagioclase phenocrysts (An 65 to 80), which are sometimes zoned, show signs of resorption and may be xenocrysts. Occasionally, spinel microphenocrysts are to be observed.

Low-temperature alteration is pervasive in these rocks. Besides variously colored smectites, calcite and pyrite occur in vesicles, veinlets, and cracks, and many basalt pieces are surrounded by a thin coating of green, blue, or yellowish brown material. When cut, a thick (up to $40 \mathrm{~mm}$ ) alteration rim is to be seen, which is darker than the fresh core of the pieces. Also, no evidence for hydrothermal alteration has been found in these basalts.

Dredged basalts. The basalts recovered by dredging represent pillow fragments. They show quench textures typical of pillow lavas and range from aphyric to plagioclase, or less frequently, to plagioclase-olivine phyric types. In general, they are akin to the drilled basaltic material already described. Sometimes, the pieces are coated by a manganese crust, and, not infrequently, fresh glassy rinds up to $20-30 \mathrm{~mm}$ thick are preserved.

The Sonne-12 dredge samples provided sufficient fresh glassy material for major and trace element analyses, including the determination of volatiles.

\section{MAJOR AND TRACE ELEMENT CHEMISTRY}

\section{ANALYTICAL PROCEDURES}

A suite of 38 basalt samples recovered from Holes 424 (14), 424A (2), 424B (6), 424C (2), and 425 (15) were analyzed by us for all major and 23 trace elements, including 10 rare earth elements. Analytical methods applied and results obtained have been reported elsewhere (Srivastava et al., 1980).

From the basement material drilled during the first part of DSDP Leg 70, we selected 20 samples for detailed chemical studies: 3 from Hole 506G, 4 from Hole 507B, and 13 from Hole 510. Table 3 lists our sample numbers and corresponding standard DSDP sample designations. For the sake of brevity, our sample numbers will be used throughout this report. All samples were analyzed for their major components, including $\mathrm{H}_{2} \mathrm{O}^{+}$and $\mathrm{CO}_{2}$; additionally, 23 trace elements have been determined. Analytical techniques applied were the following:

1) X-ray fluorescence analyses (XRF), for the determination of $\mathrm{Si}$, $\mathrm{Ti}, \mathrm{Al}, \mathrm{Fe}, \mathrm{Mn}, \mathrm{Mg}, \mathrm{Ca}, \mathrm{Na}, \mathrm{K}, \mathrm{P}, \mathrm{Zr}, \mathrm{Y}, \mathrm{Sr}, \mathrm{Zn}$, and $\mathrm{Ni}$. The analyses were carried out on fused glass beads of lithium metaborate (rock to flux ratio, 1:4) by routine XRF techniques, using a Philips PW 1450 computerized spectrometer. For concentration calculations the Philips "alphas" program was used.

2) Instrumental neutron activation analyses (INAA) were made for $\mathrm{Fe}, \mathrm{Mn}, \mathrm{Na}, \mathrm{Sc}, \mathrm{Cr}, \mathrm{Co}, \mathrm{Hf}, \mathrm{Ta}$ as well as the REE La, Ce, Nd, $\mathrm{Sm}, \mathrm{Eu}, \mathrm{Gd}, \mathrm{Tb}, \mathrm{Dy}, \mathrm{Yb}$, and $\mathrm{Lu}$. The analytical procedure adopted has been described by Kramar and Puchelt (in press).

3) Atomic absorption spectrometry (AAS), using a Varian AA6 for $\mathrm{V}, \mathrm{Cr}, \mathrm{Ni}, \mathrm{Cu}$, and $\mathrm{Zn}$.

4) Coulometric titration for $\mathrm{CO}_{2}$ and $\mathrm{S}$. rock.

5) Karl Fischer titration of $\mathrm{H}_{2} \mathrm{O}^{+}$after thermal decomposition of

6) Manganometric titration of ferrous iron. 
Table 3. Correlation of authors' and DSDP designations for Leg 70 samples.

\begin{tabular}{cl}
\hline $\begin{array}{c}\text { Authors' } \\
\text { Designation }\end{array}$ & \multicolumn{1}{c}{$\begin{array}{c}\text { DSDP Sample } \\
\text { (interval in cm) }\end{array}$} \\
\hline 5201 & $506 \mathrm{G}-2-1,65-69$ \\
5241 & $506 \mathrm{G}-2-1,69-72$ \\
5202 & $506 \mathrm{G}-2-1,123-124$ \\
5211 & $507 \mathrm{~B}-1-1,2-5$ \\
5212 & $507 \mathrm{~B}-1-1,15-18$ \\
5213 & $507 \mathrm{~B}-1-1,26-28$ \\
5243 & $507 \mathrm{~B}-2-1,16-18$ \\
5221 & $510-9-1,21-25$ \\
5245 & $510-9-1,58-60$ \\
5222 & $510-9-1,90-93$ \\
5223 & $510-9-2,3-6$ \\
5224 & $510-9-2,16-18$ \\
5249 & $510-9-2,24-27$ \\
5225 & $510-9-2,91-93$ \\
5226 & $510-9-3,3-6$ \\
5227 & $510-10-1,21-23$ \\
5228 & $510-10-1,69-83$ \\
5229 & $510-11-1,21-24$ \\
5230 & $510-11-1,42-45$ \\
5231 & $510-11-1,48-51$ \\
\hline
\end{tabular}

For the following elements, the concentrations were found to be below detection limits (detection limit and method used in parentheses): Rb (3 ppm, XRF); Nb (3 ppm, XRF); Ba (50 ppm, XRF); Cs (0.7 ppm, INAA); Sb (0.5 ppm, INAA); Th (<1 ppm, INAA); and U $(<1 \mathrm{ppm}$, INAA)

Precision was tested by replicate measurements of selected samples; accuracy was always checked by carrying the reference rocks BCR-1 and BHVO-1 through the whole procedure along with the basalt samples. The values obtained by us for BCR-1 and BHVO-1 are summarized in Table 4 (data from Puchelt and Kramar, 1981 and Kramar and Puchelt, in press). This table also contains our data for the three interlaboratory "standards," which were distributed among the laboratories involved in the analyses of Leg 69 and 70 basalts (cf. Hubberten, et al., in press).

\section{Results}

Major element analyses of basalts from Holes 506, 507B, and 510, along with their normative mineralogies calculated from these data, are given in Table 5. In Table 6 the trace element data are presented.

Table 7 shows the average chemical composition of basalts from Holes 424, 424A, 424B, and 424C and of the three petrographic types recovered from Hole 425 (designated as I to III from top to bottom).

Some of our results obtained on Sonne-12 dredge samples are listed in Table 8; the complete data set were published elsewhere (Puchelt and Emmermann, in press). Included in this table are data already published for basaltic material from dredge hauls D-1 (De Steiguer cruise 41, our No. 7; Schilling et al., 1976; Melson et al., 1977), D-17 (Southtow 7, our No. 12; Anderson et al., 1975), 6D (Cocotow 4, our No. 12; Schilling et al., 1976), D-3 (De Steiguer cruise 41, our No. 13; Schilling et al., 1976). The respective values of $(\mathrm{La} / \mathrm{Sm})_{\mathrm{N}}$ and $\mathrm{Yb}_{\mathrm{N}}$ for these dredge samples are given in Table 2 .

Prior to evaluating the chemical data, it is necessary to consider to what extent the primary composition of the basaltic material analyzed is affected by low-temperature seawater interaction or hydrothermal alteration.
Table 4. Major and trace element data obtained from authors' laboratory on BCR-1 (Kramar and Puchelt, in press) and BHVO-1 (Puchelt and Kramar, 1981), plus the three interlaboratory "standards" prepared for laboratories involved in the analyses of basalts from Legs 69 and 70.

\begin{tabular}{|c|c|c|c|c|c|}
\hline & BCR-1 & BHVO-I & IC 1 & IC 2 & IC 3 \\
\hline $\mathrm{SiO}_{2}$ & 54.3 & 49.8 & 50.1 & 50.0 & 49.0 \\
\hline $\mathrm{TiO}_{2}$ & 2.31 & 2.77 & 0.75 & 0.91 & 0.78 \\
\hline $\mathrm{Al}_{2} \mathrm{O}_{3}$ & 13.6 & 14.08 & 15.5 & 15.0 & 16.2 \\
\hline $\mathrm{Fe}_{2} \mathrm{O}_{3}$ & 3.82 & 3.16 & 1.83 & 2.38 & 1.89 \\
\hline $\mathrm{FeO}$ & 8.63 & 8.10 & 7.01 & 7.25 & 6.64 \\
\hline $\mathrm{CaO}$ & 7.03 & 11.53 & 13.7 & 12.6 & 13.2 \\
\hline $\mathrm{MgO}$ & 3.57 & 7.42 & 8.39 & 8.32 & 8.78 \\
\hline $\mathrm{MnO}$ & 0.19 & 0.17 & 0.16 & 0.17 & 0.15 \\
\hline $\mathrm{Na}_{2} \mathrm{O}$ & 3.33 & 2.26 & 1.99 & 2.31 & 2.09 \\
\hline $\mathrm{K}_{2} \mathrm{O}$ & 1.85 & 0.60 & 0.02 & 0.01 & 0.01 \\
\hline $\mathrm{P}_{2} \mathrm{O}_{5}$ & 0.35 & 0.31 & 0.05 & 0.06 & 0.03 \\
\hline $\mathrm{H}_{2} \mathrm{O}^{+}$ & 0.82 & 0.20 & 0.38 & 0.62 & 0.68 \\
\hline $\mathrm{CO}_{2}$ & $<0.1$ & $<0.1$ & 0.18 & 0.14 & 0.14 \\
\hline $\mathrm{Sc}$ & 31.8 & 31.6 & 42.4 & 46.6 & - \\
\hline V & 400 & 311 & 250 & 291 & 270 \\
\hline $\mathrm{Cr}$ & 13 & 276 & 425 & 377 & 462 \\
\hline Co & 36.5 & 46.7 & 42.8 & 44.1 & 41.4 \\
\hline $\mathrm{Ni}$ & 15 & 118 & 77 & 91 & 131 \\
\hline $\mathrm{Cu}$ & 15 & 144 & 108 & 97 & 86 \\
\hline $\mathrm{Zn}$ & 114 & 120 & 66 & 83 & 67 \\
\hline $\mathrm{Zr}$ & 185 & 170 & 31 & 41 & 35 \\
\hline Y & n.d. & 25 & 23 & 28 & 27 \\
\hline Hf & 4.73 & 4.31 & 1.06 & 1.29 & 1.19 \\
\hline $\mathrm{La}$ & 27.3 & 17.4 & 0.87 & 1.15 & 0.78 \\
\hline $\mathrm{Ce}$ & 50.7 & 37.3 & 2.4 & 5.4 & 4.1 \\
\hline $\mathrm{Nd}$ & 29.0 & 24 & 3.08 & 4.07 & 3.34 \\
\hline $\mathrm{Sm}$ & 6.93 & 6.67 & 1.52 & 2.01 & 1.72 \\
\hline Eu & 1.94 & 2.05 & 0.62 & 0.81 & 0.72 \\
\hline Gd & 5.9 & n.d. & 2.90 & 3.59 & 2.74 \\
\hline $\mathrm{Tb}$ & 1.16 & 0.91 & 0.48 & 0.65 & 0.52 \\
\hline Ho & 1.33 & n.d. & 0.83 & 0.91 & 0.76 \\
\hline $\mathrm{Tm}$ & 0.47 & n.d. & 0.41 & 0.46 & 0.37 \\
\hline $\mathrm{Yb}$ & 3.42 & 2.10 & 2.19 & 2.91 & 2.48 \\
\hline $\mathrm{Lu}$ & 0.49 & - & 0.32 & 0.46 & 0.37 \\
\hline
\end{tabular}

Because of the complexity of processes involved, no generally applicable alteration parameters can be used. But the experience of many investigators indicates that the concentration of $\mathrm{H}_{2} \mathrm{O}^{+}, \mathrm{CO}_{2}$, and $\mathrm{K}_{2} \mathrm{O}$, as well as the oxidation state (expressed by the molar ratio $\mathrm{Fe}^{3+} /$ $\mathrm{Fe}^{2+}+\mathrm{Fe}^{3+}$ ), are heavily affected by secondary processes and can thus be used as reliable indicators of the freshness of basalts. Since we have new chemical data at hand, which have been obtained on fresh basalt glasses dredged along the East Pacific Rise and the Galapagos Spreading Center (Puchelt and Emmermann, 1981), we are able to define the following limits for fresh basaltic material: $\mathrm{H}_{2} \mathrm{O}^{+} \leq 0.50$ wt. $\%, \mathrm{CO}_{2} \leq 0.15$ wt. $\%, \mathrm{~K}_{2} \mathrm{O}$ $\leq 0.25$ wt. $\%$, and $\mathrm{Fe}^{3+} / \mathrm{Fe}^{2+}+\mathrm{Fe}^{3+} \leq 0.15$. Applying these freshness criteria to Leg 54 and Leg 70 basalts, most samples analyzed can be regarded as very fresh, and only a few have to be classified as slightly altered.

Erzinger (1981) has shown that $\mathrm{Tl}$ is a very sensitive indicator for seawater alteration of deep sea basalts. Tl values for fresh basalts are low $(<20 \mathrm{ppb})$. Most of the investigated samples also satisfy this freshness criterion. We thus conclude that our major and trace element data represent the original composition of the basalts, when erupted onto the seafloor.

\section{Major Element Chemistry}

No significant intrahole variation was observed except for Hole 425, where a systematic compositional 
Table 5. Major element contents (in wt.\%) of Leg 70 basalts and their normative mineralogies calculated according to the CIPW-norm.

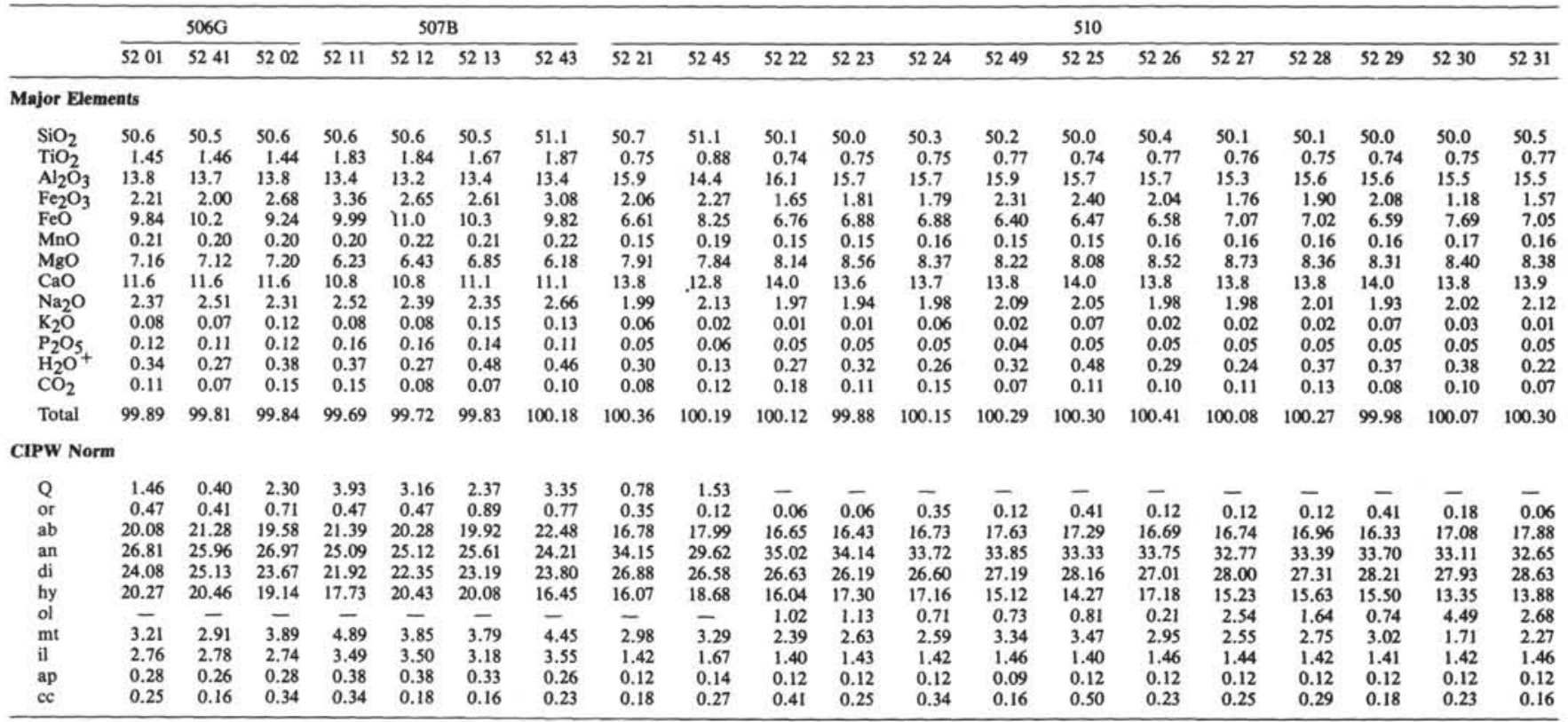

Table 6. Trace element contents (in ppm) of Leg 70 basalts.

\begin{tabular}{|c|c|c|c|c|c|c|c|c|c|c|c|c|c|c|c|c|c|c|c|c|}
\hline & \multicolumn{3}{|c|}{$506 \mathrm{G}$} & \multicolumn{4}{|c|}{$507 \mathrm{~B}$} & \multicolumn{13}{|c|}{510} \\
\hline & 5201 & 5241 & 5202 & 5211 & 5212 & 5213 & 5243 & 5221 & 5245 & 5222 & 5223 & 5224 & 5249 & 5225 & 5226 & 5227 & 5228 & 5229 & 5230 & 5231 \\
\hline $\mathbf{S}$ & 1360 & 1080 & 1100 & 1710 & 1690 & 1370 & 850 & 655 & 810 & 1030 & 760 & 365 & 1090 & 720 & 890 & 810 & 260 & 810 & 340 & n.d. \\
\hline $\mathrm{Sc}$ & 48 & n.d. & 47 & 49 & 49 & 48 & n.d. & 44 & n.d. & 42 & n.d. & 44 & n.d. & n.d. & 45 & n.d. & 42 & 45 & 44 & 46 \\
\hline v & 400 & n.d. & 375 & 475 & 450 & 425 & n.d. & 300 & n.d. & 275 & 300 & 250 & n.d. & 275 & 300 & 275 & 250 & 250 & n.d. & n.d. \\
\hline $\mathrm{Cr}$ & 162 & n.d. & 154 & 103 & 99 & 130 & n.d. & 441 & n.d. & 424 & n.d. & 439 & n.d. & n.d. & 456 & n.d. & 425 & 457 & 456 & 462 \\
\hline Co & 48 & n.d. & 47 & 50 & 50 & 47 & n.d. & 46 & n.d. & 43 & n.d. & 44 & n.d. & n.d. & 46 & n.d. & 43 & 45 & 45 & 47 \\
\hline $\mathrm{Ni}$ & 50 & 86 & 54 & 42 & 43 & 46 & 83 & 82 & 96 & 84 & 82 & 82 & 85 & 77 & 80 & 87 & 73 & 78 & 78 & 79 \\
\hline $\mathrm{Cu}$ & 81 & n.d. & 85 & 69 & 69 & 69 & n.d. & 108 & n.d. & 106 & 106 & 106 & n.d. & 110 & t10 & 110 & 108 & 108 & n.d. & n.d. \\
\hline $\mathrm{Zn}$ & 85 & 79 & 87 & 108 & 109 & 104 & 118 & 56 & 94 & 58 & 57 & 59 & 83 & 60 & 72 & 63 & 61 & 61 & 58 & 56 \\
\hline $\mathrm{Sr}$ & 68 & 72 & 69 & 71 & 69 & 68 & 80 & 54 & 56 & 63 & 53 & 58 & 55 & 56 & 56 & 66 & 52 & 59 & 52 & 54 \\
\hline $\mathbf{Y}$ & 31 & 31 & 35 & 40 & 46 & 39 & 40 & 26 & 31 & 30 & 24 & 28 & 28 & 20 & 29 & 25 & 20 & 19 & 24 & 19 \\
\hline $\mathrm{Zr}$ & 85 & 84 & 82 & 99 & 98 & 87 & 116 & 33 & 48 & 29 & 40 & 33 & 37 & 34 & 34 & 35 & 41 & 31 & 35 & 31 \\
\hline La & 2.7 & n.d. & 2.4 & 3.4 & 3.3 & 3.1 & n.d. & 0.8 & n.d. & 0.7 & n.d. & 0.7 & n.d. & n.d. & 0.8 & n.d. & 0.9 & 0.6 & 0.8 & 0.6 \\
\hline $\mathrm{Ce}$ & 9.8 & n.d. & 8.5 & 11 & 13 & 12 & n.d. & 5.3 & n.d. & 4.0 & n.d. & 4.3 & n.d. & n.d. & 4.1 & n.d. & 2.4 & 2.6 & 4.2 & 2.1 \\
\hline Nd & 8.8 & n.d. & 8.6 & 11 & 10 & 9.4 & n.d. & 4.3 & n.d. & 4.0 & n.d. & 3.8 & n.d. & n.d. & 3.8 & n.d. & 3.1 & 2.4 & 3.3 & 3.6 \\
\hline $\mathrm{Sm}$ & 3.5 & n.d. & 3.3 & 4.4 & 4.4 & 4.0 & n.d. & 1.6 & n.d. & 1.6 & n.d. & 1.6 & n.d. & n.d. & 1.7 & n.d. & 1.5 & 1.6 & 1.6 & 1.7 \\
\hline Eu & 1.25 & n.d. & 1.17 & 1.50 & 1.50 & 1.32 & n.d. & 0.64 & n.d. & 0.63 & n.d. & 0.61 & n.d. & n.d. & 0.71 & n.d. & 0.62 & 0.68 & 0.69 & 0.67 \\
\hline Gd & 5.4 & n.d. & 5.2 & 6.4 & 6.9 & 6.5 & n.d. & 3.6 & n.d. & 2.7 & n.d. & 3.0 & n.d. & n.d. & 3.4 & n.d. & 2.9 & 3.0 & 2.8 & 3.1 \\
\hline $\mathrm{Tb}$ & 0.97 & n.d. & 0.94 & 1.2 & 1.2 & 1.1 & n.d. & 0.52 & n.d. & 0.49 & n.d. & 0.55 & n.d. & n.d. & 0.58 & n.d. & 0.48 & 0.55 & 0.49 & 0.53 \\
\hline Ho & 1.1 & n.d. & 1.1 & 1.8 & 1.7 & 1.7 & n.d. & 0.79 & n.d. & 0.86 & n.d. & 0.93 & n.d. & n.d. & 0.82 & n.d. & 0.83 & 0.60 & 0.71 & 0.88 \\
\hline $\mathrm{Yb}$ & 4.5 & n.d. & 4.2 & 5.6 & 5.6 & 5.2 & n.d. & 2.5 & n.d. & 2.4 & n.d. & 2.4 & n.d. & n.d. & 2.4 & n.d. & 2.2 & 2.3 & 2.3 & 2.5 \\
\hline L.u & 0.63 & n.d. & 0.60 & 0.79 & 0.81 & 0.68 & n.d. & 0.34 & n.d. & 0.33 & n.d. & 0.38 & n.d. & n.d. & 0.40 & n.d. & 0.32 & 0.36 & 0.35 & 0.32 \\
\hline Hf & 2.3 & n.d. & 2.2 & 3.3 & 3.2 & 2.7 & n.d. & 0.9 & n.d. & 1.1 & n.d. & 1.0 & n.d. & n.d. & 1.2 & n.d. & 1.1 & 1.0 & 1.2 & 1.1 \\
\hline $\mathrm{Ta}$ & 0.14 & n.d. & 0.13 & 0.16 & 0.16 & 0.16 & n.d. & $<0.03$ & n.d. & $<0.03$ & n.d. & $<0.03$ & n.d. & n.d. & $<0.03$ & n.d. & $<0.03$ & $<0.03$ & $<0.03$ & $<0.03$ \\
\hline
\end{tabular}

Table 7. Average compositions of basalts from Sites 424 and 425 (in wt. $\% / \mathrm{ppm}$ ).

\begin{tabular}{|c|c|c|c|c|c|c|c|}
\hline & $\begin{array}{l}424 \\
\dot{x}=14\end{array}$ & $\begin{array}{l}424 \mathrm{~A} \\
\bar{x}=2\end{array}$ & $\begin{array}{l}424 \mathrm{~B} \\
\overrightarrow{\mathrm{x}}=6\end{array}$ & $\begin{array}{l}424 C \\
\bar{x}=2\end{array}$ & $\begin{array}{c}\text { 425, Type I } \\
\overline{\mathrm{x}}=3\end{array}$ & $\begin{array}{c}\text { 425, Type II } \\
\overline{\bar{x}}=4\end{array}$ & $\begin{array}{c}\text { 425, Type III } \\
x=8\end{array}$ \\
\hline $\mathrm{SiO}_{2}$ & 50.9 & 51.9 & 51.0 & 50.9 & 51.0 & 50.6 & 50.4 \\
\hline $\mathrm{TiO}_{2}$ & 1.88 & 1.77 & 1.78 & 1.88 & 1.35 & 1.20 & 0.98 \\
\hline $\mathrm{Al}_{2} \mathrm{O}_{3}$ & 12.9 & 12.8 & 13.3 & 12.8 & 13.8 & 14.1 & 14.3 \\
\hline $\mathrm{FeO}_{\mathrm{T}}$ & 12.8 & 12.8 & 12.8 & 12.7 & 11.8 & 11.0 & 10.4 \\
\hline MnO & 0.21 & 0.22 & 0.21 & 0.23 & 0.19 & 0.18 & 0.17 \\
\hline $\mathrm{MgO}$ & 6.44 & 5.98 & 6.33 & 6.63 & 7.60 & 8.08 & 8.33 \\
\hline $\mathrm{CaO}$ & 10.4 & 10.5 & 10.0 & 10.7 & 11.4 & 11.8 & 11.9 \\
\hline $\mathrm{Na}_{2} \mathrm{O}$ & 2.40 & 2.34 & 2.38 & 2.29 & 2.17 & 1.93 & 1.93 \\
\hline $\mathrm{K}_{2} \mathrm{O}$ & 0.09 & 0.11 & 0.11 & 0.13 & 0.07 & 0.04 & 0.04 \\
\hline $\mathrm{P}_{2} \mathrm{O}_{5}$ & 0.18 & 0.19 & 0.19 & 0.16 & 0.12 & 0.11 & 0.10 \\
\hline Sc & 43 & 44 & 44 & 43 & 44 & 43 & 48 \\
\hline $\mathrm{Cr}$ & 62 & 68 & 61 & 71 & 126 & 225 & 269 \\
\hline $\begin{array}{c}\text { Co } \\
\text {. }\end{array}$ & 47 & 47 & 47 & 47 & 48 & 45 & 48 \\
\hline $\mathrm{Ni}$ & $\begin{array}{l}48 \\
59\end{array}$ & 52 & 55 & 33 & 52 & 61 & 70 \\
\hline $\mathrm{Cu}$ & 59 & 63 & 61 & 51 & 62 & 68 & 73 \\
\hline $\begin{array}{l}\mathrm{Zn} \\
\mathrm{Sr}\end{array}$ & 101 & 111 & 108 & 116 & 95 & 75 & 78 \\
\hline $\begin{array}{l}\text { Sr } \\
\mathrm{Y}\end{array}$ & $\begin{array}{l}66 \\
38\end{array}$ & $\begin{array}{l}68 \\
\end{array}$ & 67 & 63 & 56 & 54 & 56 \\
\hline $\begin{array}{l}\mathrm{Y} \\
\mathrm{Zr}\end{array}$ & $\begin{array}{r}38 \\
121\end{array}$ & $\begin{array}{c}41 \\
130\end{array}$ & $\begin{array}{r}40 \\
117\end{array}$ & $\begin{array}{r}38 \\
124\end{array}$ & $\begin{array}{l}30 \\
80 \\
80\end{array}$ & $\begin{array}{l}26 \\
67\end{array}$ & $\begin{array}{l}24 \\
47\end{array}$ \\
\hline $\mathrm{Hf}$ & 3.2 & 3,1 & 2.8 & 2.6 & 1.8 & 1.4 & 1.0 \\
\hline
\end{tabular}

downhole variation could be established. The basement sections encountered at the different drill locations can thus be regarded as rather uniform in composition. Furthermore, close scrutiny of Tables 5 and 7 reveals that basalts recovered from various holes drilled within the mounds area are very similar in their overall chemistry, whereas there are pronounced differences between these young basalts and older basalts drilled at the northern flank of the Galapagos rift. In keeping with their petrography, basalts from Holes 425 and 510 are higher in $\mathrm{MgO}, \mathrm{CaO}$, and $\mathrm{Al}_{2} \mathrm{O}_{3}$ and lower in $\mathrm{FeO}^{\mathrm{T}}, \mathrm{TiO}_{2}, \mathrm{Na}_{2} \mathrm{O}$, $\mathrm{K}_{2} \mathrm{O}$, and $\mathrm{P}_{2} \mathrm{O}_{5}$ than young crust basalts. The existing relations and differences between basalt from the various drill holes are especially well displayed in $\mathrm{MgO}$-variation diagrams of some selected major oxides (Fig. 2). As can be seen from this figure, basalts from all drill localities exhibit systematic compositional variations de- 
Table 8. Major element contents (in wt. \%) of basaltic glasses from different dredge stations along the Galapagos Rift (see Tables 1 and 2 for sample numbers).

\begin{tabular}{lcccccccccccc}
\hline $\begin{array}{c}\text { Major } \\
\text { Elements }\end{array}$ & $7^{\mathrm{a}}$ & Glasses $7 \mathrm{~b}$ & 8 & 6 & 9 & 10 & $11^{\mathrm{c}}$ & $12^{\mathrm{a}}$ & $13^{\mathrm{a}}$ & $14^{\mathrm{a}}$ & 17 & 3 \\
\hline $\mathrm{SiO}_{2}$ & 48.4 & $(50.3-49.2)$ & 50.0 & 50.2 & 50.7 & 50.4 & 49.9 & & 50.7 & 49.8 & 50.3 & 51.5 \\
$\mathrm{TiO}_{2}$ & 3.62 & $(2.90-3.76)$ & 2.51 & 2.22 & 2.03 & 2.01 & 2.07 & 1.88 & 1.22 & 1.10 & 0.90 & 1.92 \\
$\mathrm{Al}_{2} \mathrm{O}_{3}$ & 11.5 & $(12.7-11.3)$ & 12.9 & 13.1 & 13.5 & 13.3 & 13.0 & & 16.0 & 15.7 & 15.2 & 13.7 \\
$\mathrm{FeO}^{2}$ & 18.3 & $(15.4-18.7)$ & 14.9 & 14.0 & 13.6 & 13.2 & 13.0 & 12.9 & 9.06 & 9.10 & 8.70 & 11.8 \\
$\mathrm{MnO}$ & 0.26 & $($ (n.d.) & 0.23 & 0.22 & 0.22 & 0.22 & 0.20 & & 0.17 & 0.16 & 0.15 & 0.22 \\
$\mathrm{MgO}$ & 4.33 & $(5.56-4.21)$ & 5.67 & 6.27 & 6.35 & 6.50 & 5.84 & 6.62 & 6.38 & 9.00 & 8.93 & 6.65 \\
$\mathrm{CaO}$ & 8.95 & $(9.94-9.33)$ & 10.1 & 10.6 & 10.7 & 10.7 & 10.6 & & 12.5 & 12.1 & 13.0 & 11.0 \\
$\mathrm{Na}_{2} \mathrm{O}$ & 2.66 & $(2.45-2.48)$ & 2.51 & 2.35 & 2.28 & 2.29 & 2.59 & & 2.33 & 2.26 & 2.23 & 2.28 \\
$\mathrm{~K}_{2} \mathrm{O}$ & 0.24 & $(0.10-0.19)$ & 0.18 & 0.14 & 0.16 & 0.17 & 0.15 & & 0.14 & 0.07 & 0.06 & 0.12 \\
$\mathrm{P}_{2} \mathrm{O}_{5}$ & 0.32 & $(0.24-0.31)$ & 0.24 & 0.20 & 0.19 & 0.20 & 0.20 & & 0.11 & 0.11 & 0.05 & 0.16 \\
\hline
\end{tabular}

a Data from Schilling et al., 1976.

b Data from Melson et al., 1977.

c Data from Puchelt and Emmerman, in press.
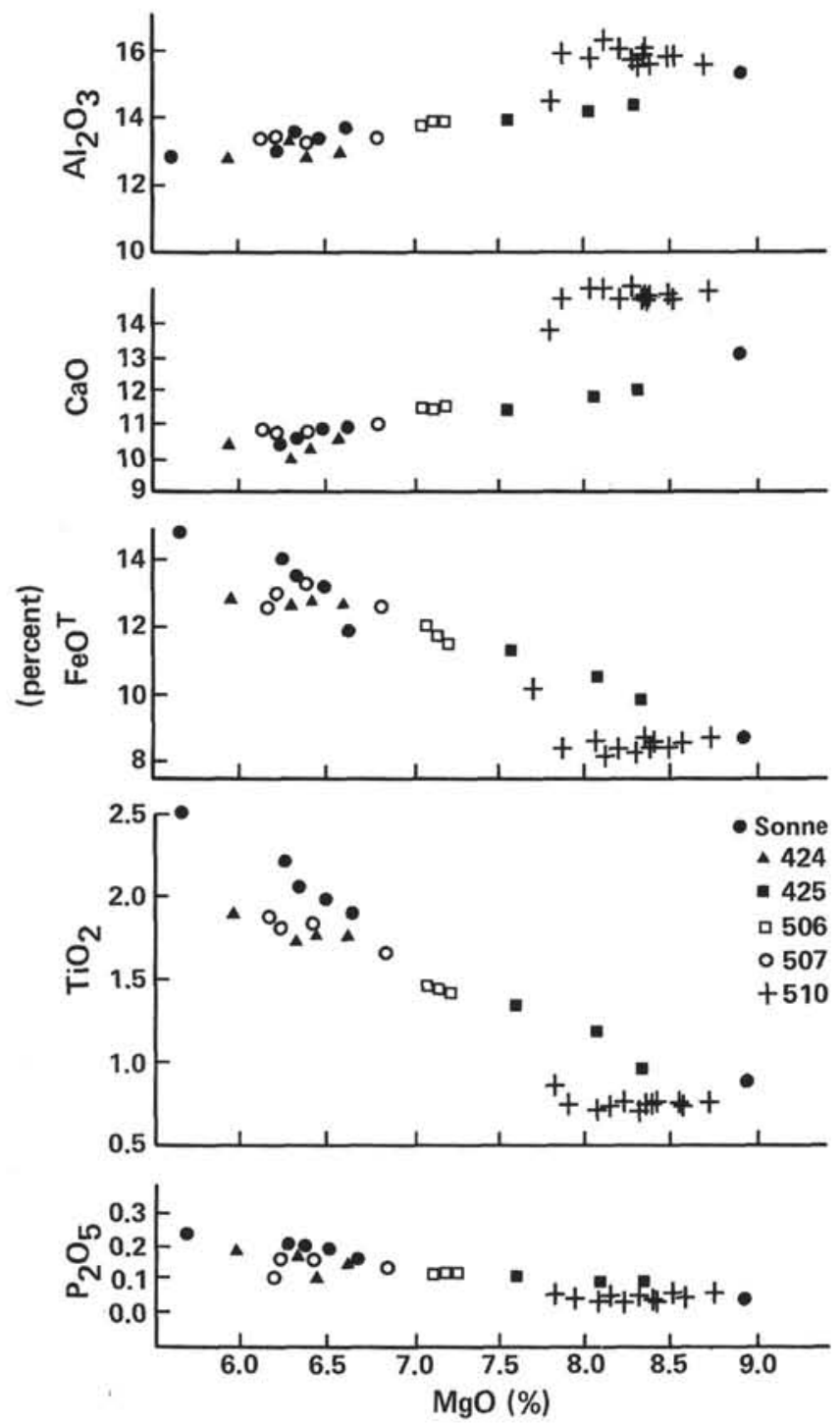

Figure 2. MgO-variation diagram of selected major oxides of basalts from DSDP Legs 54 and 70 and basaltic glasses from dredge stations of Sonne-12 cruise (cf. Puchelt and Emmermann, in press). fining clear chemical trends except Hole 510 basalts, which plot outside this general trend. In comparison to Hole 425 basalts, which almost cover the same range of $\mathrm{MgO}$-variation, Hole 510 basalts vary rather irregularly and are enriched in $\mathrm{CaO}$ and $\mathrm{Al}_{2} \mathrm{O}_{3}$ but have low $\mathrm{FeO}^{\mathrm{T}}$ and $\mathrm{TiO}_{2}$.

According to their normative mineralogies all basalts can be classified as tholeiites ranging from olivine to quartz normative types (Fig. 3). Basalts from Hole 510 as well as Type III basalts from Hole 425 plot in the olivine tholeiite field, whereas basalts from the mounds area are quartz normative with quartz contents of up to $4 \mathrm{wt} . \%$. The normative An-content of plagioclase, which is a good estimate of the actual An-content pres-

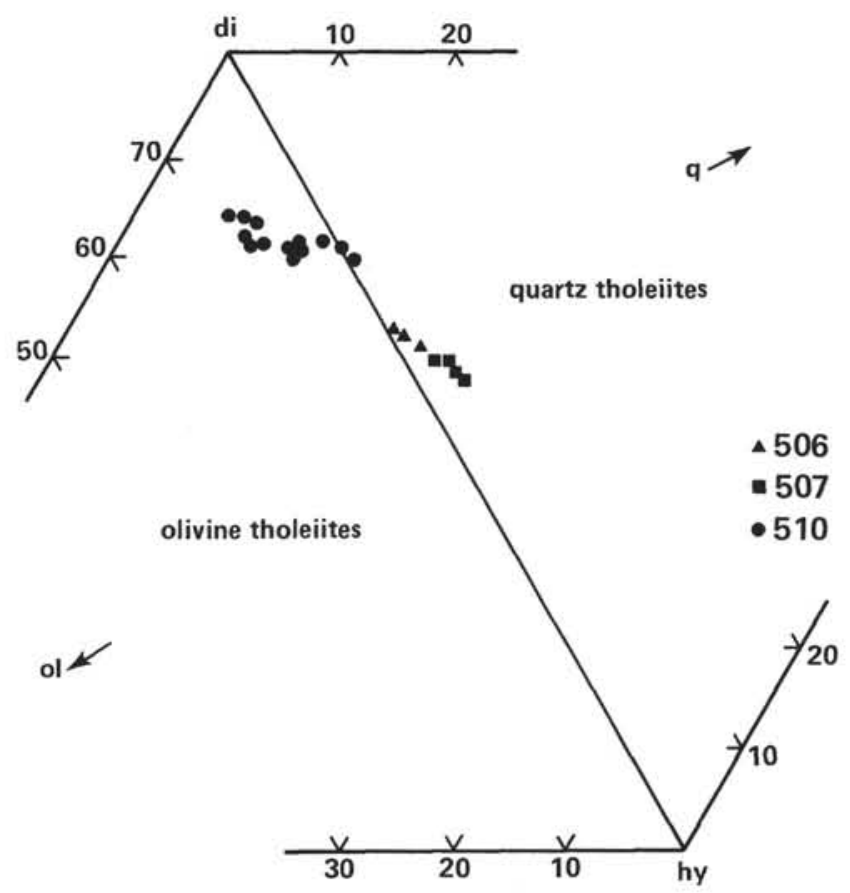

Figure 3. Olivine-diopside-hyperthene-quartz diagram for Leg 70 basalts. 
ent, is $57 \%$ for Hole $506 \mathrm{G}$ basalts, $55 \%$ for Hole 507B basalts, and $66 \%$ for Hole 510 basalts, respectively.

\section{Trace Element Chemistry}

The differences in major element composition between young and older crust basalts are also reflected in their trace element chemistry. In general, young crust basalts are significantly higher in $\mathrm{Zr}, \mathrm{Hf}$, and $\mathrm{Ta}$ and lower in $\mathrm{Cr}$ as well as $\mathrm{Ni}$ than older crust basalts. As with major oxides systematic and continuous trends are to be observed in MgO-variation diagrams (Fig. 4). Also, in this case, Hole 510 basalts do not fit into the general pattern, being either too high or too low in their trace element concentrations when compared to the extrapolated variation trends. This is most pronounced with chromium, which is quite high in Hole 510 basalts.

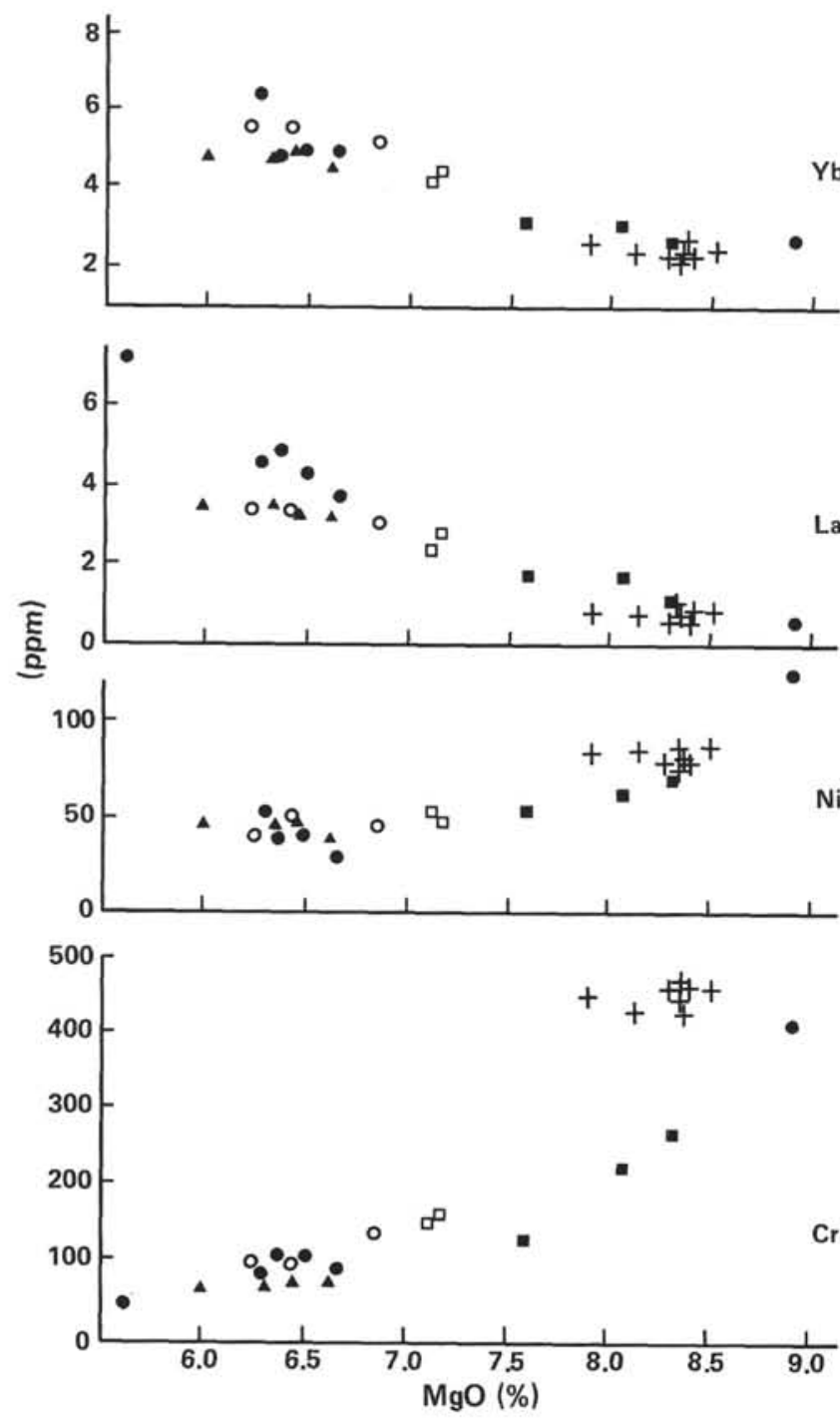

Figure 4. MgO-variation diagram of some selected trace elements of basalts from DSDP Legs 54 and 70 and basaltic glasses from dredge stations of Sonne-12 cruise (cf. Puchelt and Emmermann, in press).
In their chondrite normalized rare-earth element patterns all basalts are characterized by a depletion of the light rare-earth elements over the heavier ones. This is to be seen from Figures 5 and 6, which show the range of rare-earth element variation or representative rare-earth element patterns of basalts from the various drill holes. Differences exist in the degree of depletion, which can be expressed by the chondrite-normalized La/Sm ratio, and the enrichment level of the heavy rare-earth elements, which is expressed by the $\mathrm{Yb}$ enrichment factor, designated as $\mathrm{Yb}_{\mathrm{N}}$. According to these criteria, Hole 510 basalts are most depleted in light rare-earth elements with $(\mathrm{La} / \mathrm{Sm})_{\mathrm{N}}$ varying between 0.22 and 0.36 ; and they have the lowest heavy rare-earth element enrichment level, with $\mathrm{Yb}_{\mathrm{N}}$ ranging from 10.6 to 12.0. The respective values for young crust basalts are: $(\mathrm{La} / \mathrm{Sm})_{N}, 0.47$ to 0.55 and $\mathrm{Yb}_{\mathrm{N}}, 20.2$ to 27.0. Some samples have weak negative $\mathrm{Eu}$ anomalies. This is especially so for Site 424
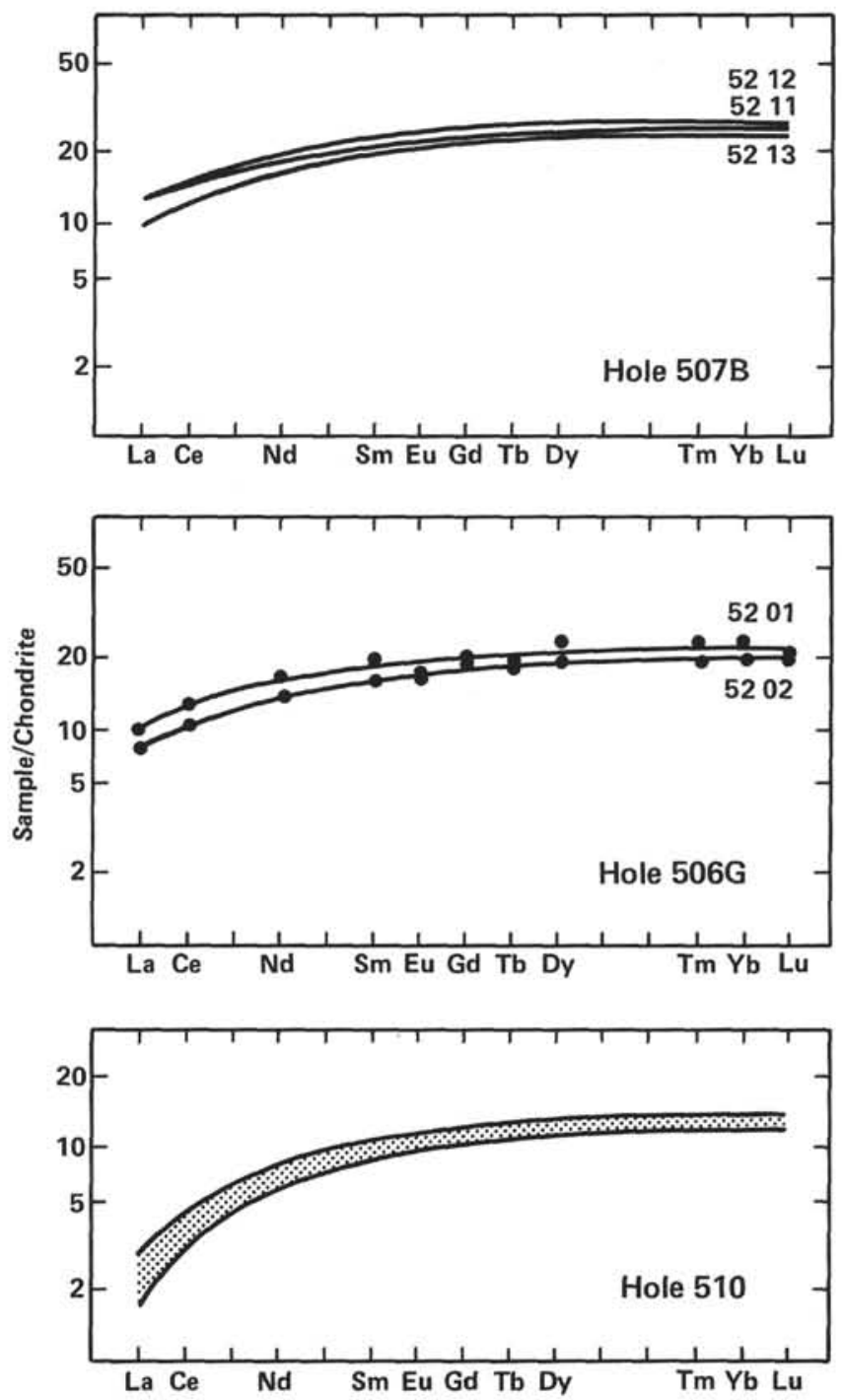

Figure 5. Chondrite-normalized rare-earth element patterns of basalts from Holes 507B, 506G, and 510 (DSDP Leg 70). 


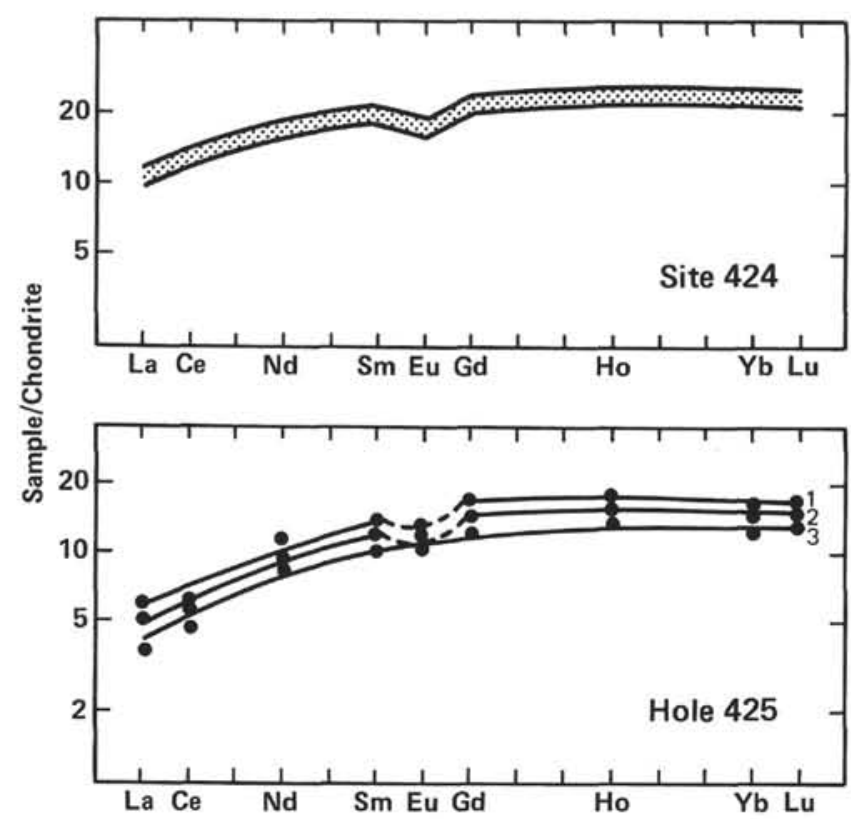

Figure 6. Chondrite-normalized rare-earth element patterns of basalts from Sites 424 and 425 (DSDP Leg 54).

basalts, which show the highest overall enrichment of rare-earth elements (Fig. 7).

\section{DISCUSSION}

The data presented here can be extended by incorporating our results from Sonne-12 dredge samples (Puchelt and Emmermann, 1981; in press) and of already published analyses of basaltic material recovered from this very area by previous dredge hauls (see Table 8). Taken together the numerous chemical data now available provide the opportunity to make reliable state-

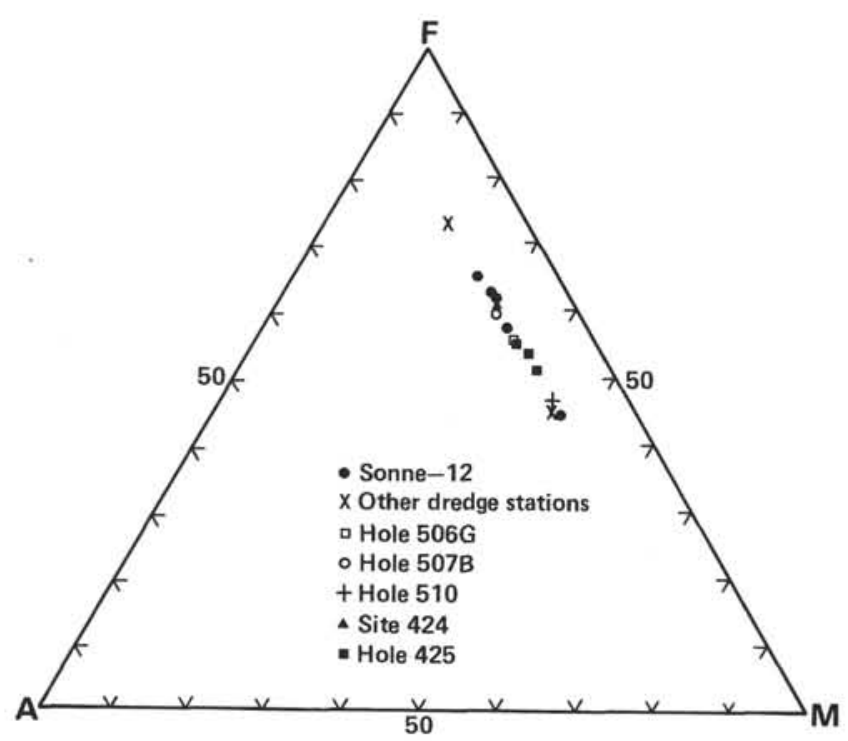

Figure 7. AFM diagram of dredged basaltic material (Sonne-12 cruise and other dredge stations) and mean values of the basalts drilled at DSDP sites. For Hole 425 the mean of each of the three different basalt types is plotted. ments on the composition of the uppermost crust generated at the GSC between longitudes $85^{\circ}$ and $87^{\circ} \mathrm{W}$ and to answer the question of whether there are any systematic compositional variations along and across the rift.

Analyses of major elements of basaltic material dredged from different stations along the axis of the $\mathrm{Ga}-$ lapagos rift are summarized in Table 8 (Nos. 6 to 12; see also Fig. 1). The arrangement of data is according to the longitudinal position of the dredge stations starting with station No. 7 (De Steigner cruise 41, dredge D-17, Table 2) being the easternmost dredge locality. As may be seen from this table, there seems to be a systematic compositional trend along the rift axis which is most pronounced with $\mathrm{FeO}^{\mathrm{T}}$ and $\mathrm{TiO}_{2}$. Zero-age basalts with highest concentrations of $\mathrm{FeO}^{\mathrm{T}}$ (up to $18.7 \%$ ) and $\mathrm{TiO}_{2}$ (up to $3.76 \%$ ) occur at the eastern border of the Galapagos rift close to the Ecuador fracture zone. The numerous glass analyses that have been published from this dredge station (Melson et al., 1977) demonstrate that basaltic liquids with varying degrees of iron and titanium enrichment were erupted at this site. The lowest $\mathrm{FeO}^{\mathrm{T}}$ value obtained on basalt glasses is $15.4 \%$ and the highest $18.7 \%$ (Table 8 , No. $7 \mathrm{~b}$ in parentheses) with a continuous series of intermediate glass compositions in between. Basalt glasses recovered from the inner rift zone further westward invariably have lower $\mathrm{FeO}^{\mathrm{T}}$ and $\mathrm{TiO}_{2}$ contents with both components decreasing systematically from station 7 to station 12-that is, from east to west along the rift axis. According to their iron and titanium concentrations, which are the highest of all basalt types recovered from this area, zero-age basalts constitute what have been termed FeTi-tholeiites. Chemically, they grade into young crust basalts, which on the average are lower in $\mathrm{FeO}^{\mathrm{T}}$ and $\mathrm{TiO}_{2}$, but in comparison to "normal" midocean ridge basalts (MORB) have to be classified as $\mathrm{Fe}$ - and $\mathrm{Ti}$-enriched tholeiites.

The chemical spectrum of drilled and dredged basaltic material is displayed in Figures 2 and 4. Solid points represent the basement composition at the various dredge stations of the Sonne-12 cruise (see also Table 2). As is obvious from these variation diagrams, the different basalt types are closely related to each other and are apparently connected by a systematic and continuous compositional development. The chemical trends are especially well defined by the Sonne-12 samples, which just cover the entire range of variation of drilled basaltic material. Since these data represent glass samples, i.e., liquid compositions, it is tempting to explain the compositional evolution as a result of intense low-pressure fractional crystallization of tholeiitic melts. This interpretation is also supported by the fact that on an AFM-diagram (Fig. 7) all basalts fall on a Skaergaard-type fractionation trend with extreme iron enrichment reaching $18.7 \% \mathrm{FeO}^{\mathrm{T}}$.

Basalts from Sites 506-509, 424, and 425 closely follow the chemical trends as defined by Sonne-12 glass samples, which supports the assumption that they represent magma compositions, each basalt type compositionally reflecting a specific stage in the course of differentiation. Basalts from Hole 510 deviate distinctly 
from this general trend. They plot outside the "line of liquid descent" as represented by the glass compositions (see Figs. 2 and 4 for comparison) and show a larger variability only with the $\mathrm{MgO}$ values, whereas the concentrations of all other elements are rather constant. Very striking are the unusually high $\mathrm{CaO}$ concentrations which have not been reported so far for basaltic glasses collected over all oceans (Melson et al., 1977). As a result of this fact, and in keeping with their petrography, we concluded that Hole 510 basalts do not represent magma compositions, but rather have to be regarded as a mixture of tholeiitic liquid plus plagioclase xenocrysts. From the $\mathrm{CaO}$ enrichment, which is on average $2.5 \mathrm{wt} . \%$ over the general level as defined by glass compositions, the portion of plagioclase xenocrysts can be estimated to be approximately $20 \%$.

The uptake of plagioclase crystals results in an enrichment of $\mathrm{CaO}$ as well as $\mathrm{Al}_{2} \mathrm{O}_{3}$ and in a corresponding depletion in all elements not contained in plagioclase, as is to be observed for $\mathrm{FeO}, \mathrm{TiO}_{2}$, and $\mathrm{P}_{2} \mathrm{O}_{5}$ (Fig. 2). Chromium poses the only exception from this expected depletion. It is, on the contrary, significantly enriched over normal concentration levels, which likewise has to be explained by addition of small quantities of spinel xenocrysts.

As is already clear from the foregoing discussion, basalts from zero-age crust, young crust, and older crust differ systematically in composition, suggesting that there might be a chemical development as a function of time. The large number of localities from which basalt analyses are available offers the unique opportunity to construct a transect across the Galapagos rift at about $86^{\circ} \mathrm{W}$ and to study basement composition with increasing distances perpendicular to the rift axis. Figure 8 shows variation in certain elements and element ratios with distance from the rift axis. The inner rift zone is indicated by the stippled area. Basalts from this zone are highest in $\mathrm{FeO}^{\mathrm{T}}$ and $\mathrm{TiO}_{2}$ and lowest in $\mathrm{MgO}$. They show the least depletion in light rare-earth elements. To the north and south of the inner rift zone, systematic chemical variations are visible with increasing distance, i.e., with progressing age. The compositional development seems to be cyclic. There are certain intervals that are characterized by a unidirectional trend resembling the liquid line of descent produced by fractional crystallization of tholeiitic magmas. North of the rift axis two such cycles seem to exist, whereas in the south only a section of one cycle is indicated in a mirror-like fashion. If this picture is real and not the result of sampling bias, it can be explained as the result of repeated, long-term differentiation cycles, each starting with strongly light rare-earth depleted olivine tholeiitic melts and ending at a certain Fe-enrichment level. The present-day situation might reflect an advanced stage within such a cycle. An additional argument in favor of long-term differentiation processes is the systematic downhole variation in composition of Hole 425 basalts. The three chemical types distinguished from bottom to top of this hole represent three distinct differentiation stages with the lowermost type being the least evolved (Fig. 2).

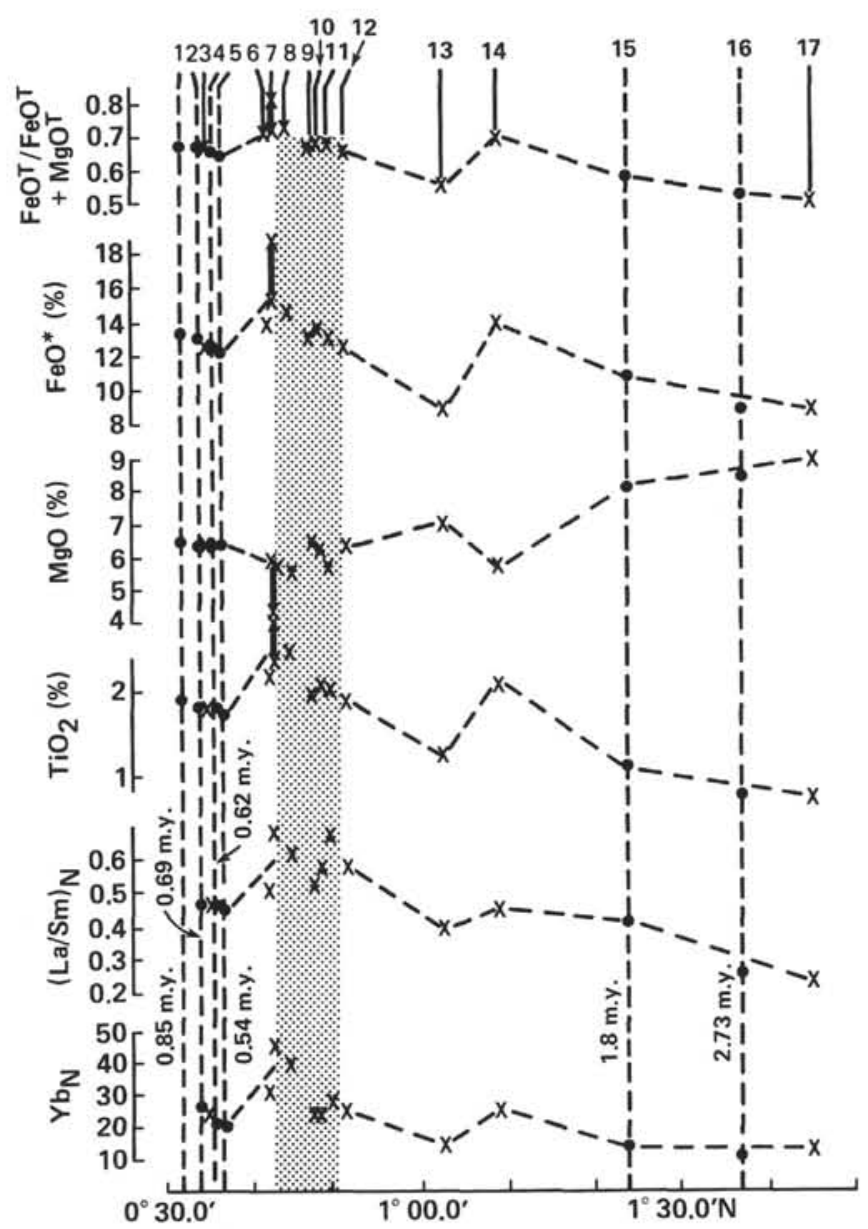

Figure 8. Variation of selected elements and element ratios with distance from the Rift axis for basaltic material from DSDP sites (solid points) and dredge locations (crosses). All sample points are projected on an $86^{\circ} \mathrm{W}$ plane. The inner rift zone is indicated by the stippled area (For sample numbers see Tables 1 and 2, and Fig. 1).

\section{CONCLUSIONS}

On the basis of the present study we want to emphasize the following points:

Basalts recovered by drilling and dredging within a crustal segment across the Galapagos rift between longitude $85^{\circ}$ and $87^{\circ} \mathrm{W}$ display a series of chemical types ranging from strongly light rare-earth depleted, normal midocean ridge basalts, to $\mathrm{Fe}$ - and Ti-enriched tholeiites, and finally to FeTi-basalts. These types are connected by a continuous compositional development, which can be plausibly explained as a liquid line of descent of tholeiitic melts. Each basalt type represents a certain stage within this course of differentiation.

From the large number of drill and dredge localities it is obvious that there are systematic compositional variations of basalts erupted at the GSC both along the rift axis and perpendicular to the rift axis. Zero-age basalts belong to the FeTi-group, young crust basalts are Feand Ti-enriched tholeiites, and older crust basalts have chemical characteristics typical of normal ocean ridge tholeiites. 
There seems to be a chemical gradient along the rift axis in that $\mathrm{Fe}$ - and $\mathrm{Ti}$-concentrations increase invariably from west to east. Basalts close to the Ecuador fracture zone are highest in both elements, with $\mathrm{FeO}^{\mathrm{T}}$ up to 18.7 wt. $\%$ and $\mathrm{TiO}_{2}$ up to 3.6 wt. $\%$.

Projecting all sample localities on a traverse at about $86^{\circ} \mathrm{W}$ suggests a compositional variation of basalts as a function of time within the last 2.7 m.y. The chemical development as shown on variation diagrams appears to be cyclic and seems to be arranged in a mirror-like fashion about the rift axis.

We explain this evolution as a result of long-term shallow depth fractional crystallization processes acting on olivine tholeiitic melts.

All basalts are characterized by light rare-earth element depleted patterns, indicating that they originated from light rare-earth element depleted magmas typical of normal midocean ridge segments being derived from a depleted mantle source.

\section{ACKNOWLEDGMENTS}

These investigations were supported by a grant from the Deutsche Forschungsgemeinschaft. Dredge samples from R/V Sonne cruise 12 were kindly placed at our disposal by Dr. Bäcker, Preussag Meerestechnik. Neutron activation analyses were carried out with equipment given by the Bundesministerium fur Forschung und Technologie.

Irradiation facilities were provided by the Gesellschaft für Kernforschung, Karlsruhe. We want to thank all individuals and institutions who supported this work.

\section{REFERENCES}

Anderson, R. N., Clague, D. A., Klitgord, K. D., Marshall, M., and Nishimori, R. K., 1975. Magnetic and petrologic variations along the Galapagos Spreading Center and their relation to the Galapagos melting anomaly. Geol. Soc. Am., Bull., 86:683-694.

Erzinger, J., 1981. Zur Geochemie von Selen und Thallium in magmatischen Gesteinen-mit einem Beitrag zur Analytik von Selen in geochemischen Matrizes [Ph.D. dissert.]. University of Karlsruhe, Germany.

Hubberten, H.-W., Honnorez, J., and the Shipboard Scientific Party, in press. Interlaboratory comparison of Legs $69 / 70$ basalt standards. In Langseth, M. G., Cann, J. R., et al., Init. Repts. DSDP, 69: Washington (U.S. Govt. Printing Office).

Kramar, U., and Puchelt, H., in press. Reproducibility for INAA trace element determinations with AGV, BCR and GSP and new data for 18 geochemical reference materials. Geostandards Newslet.

Melson, W. G., Byerly, G. R., Nelen, J. A., O'Hearn, T., Wright, T. L., and Vallier, T., 1977. A catalog of the major element chemistry of abyssal volcanic glasses. In Mason, B. (Ed.), Mineral Sciences Investigations, 1974-1975. Smithsonian contributions to the Earth Sciences No. 19:31-60.

Puchelt, H., and Emmermann, R., 1981. Basaltglaser und Basalte vom Ostpazifischen Rucken. Fortschr. Mineral. Beih., 59(1): 160-161.

, in press. Petrogenetic implications from tholeiite basalt glasses from the East Pacific Rise and the Galapagos Spreading Center. Chemical Geology.

Puchelt, H., and Kramar, U., 1981. New analytical data and homogeneity of BHVO-1. Geostandards Newslet., 5:87-94.

Schilling, J.-G., Anderson, R. N., and Vogt, P., 1976. Rare earth, Fe and $\mathrm{Ti}$ variations along the Galapagos Spreading Center, and their relationship to the Galapagos mantle plume. Nature, 261:108-113.

Srivastava, R. K., Emmermann, R., and Puchelt, H., 1980. Petrology and geochemistry of basalts from Deep Sea Drilling Project Leg 54. In Rosendahl, B. R., Hekinian, R., et al., Init. Repts. DSDP, 54: Washington (U.S. Govt. Printing Office), 671-693.

Vogt, P. R., and Johnson, G. L., 1975. Transform faults and longitudinal flow below the Midocean Ridge. J. Geophys. Res., 80: 1399-1428. 